Article

\title{
Influence of Network Embeddedness and Network Diversity on Green Innovation: The Mediation Effect of Green Social Capital
}

\author{
Yu-Shan Chen *, Cui Wang, Ying-Rong Chen, Wei-Yuan Lo and Kuan-Ling Chen \\ Department of Business Administration, National Taipei University; San Shia, New Taipei City 237, Taiwan; \\ wangcui13101014246@163.com (C.W.); cyr@ey.gov.tw (Y.-R.C.); galas912@gmail.com (W.-Y.L.); \\ klc1993@icloud.com (K.-L.C.) \\ * Correspondence: yushan@gm.ntpu.edu.tw
}

Received: 25 August 2019; Accepted: 14 October 2019; Published: 16 October 2019

\begin{abstract}
Due to the current rise in concern about the challenge of global warming, stakeholders are now more conscious than in the past regarding environmental concerns. Stakeholders are more likely than ever before to support companies that are environmentally friendly. Simultaneously, companies seek to develop their social networks in such a way as to enhance their green innovation. This study investigates the influences of network embeddedness and network diversity on green innovation. In addition, this research discusses the mediation effects of green social capital. We adopt structural equation modeling for testing the research framework. A total of 330 valid questionnaires are collected. The results demonstrate that network embeddedness positively affects green social capital and green innovation performance. However, although network diversity positively affects green innovation performance, it does not significantly influence green social capital. Furthermore, the study indicates that green social capital partially mediates the relationship between network embeddedness and green innovation performance.
\end{abstract}

Keywords: green social capital; network embeddedness; network diversity; green innovation

\section{Introduction}

Three environmental pressures-stakeholder environmentalism, environmental regulations, and competitive pressures-force firms to alter their business models and activities and adopt environmental management in the world. The considerable influence of strict environmental laws—such as those from the Paris Agreement, the Montreal Convention, the Restriction of Hazardous Substances Directive, and the Waste Electronics and Electrical Equipment Directive-and prevailing stakeholder environmentalism modify industries' patterns of competition. Not only is it necessary to adopt a proactive environmental management strategy, but it is also imperative to change business mindsets and operation activities to harness green opportunities and inspire green innovations in response to environmental pressures. Firms must use environmental management to satisfy the environmental needs of key stakeholders, such as customers, suppliers, government agencies, shareholders, and environmental communities, all of whom are strongly conscious of environmental issues, according to stakeholder theory. Several prestigious firms, such as Coca-Cola and 3M, adjust their corporate environmental management from a reactive environmental mindset to a proactive one. The prevailing trend of environmentalism is changing the world's competitive landscape. Active environmental management affects all facets of business activities [1]. The new green mindset is increasingly prevalent for business activities, such as green production, green marketing, green design, green $R \& D$, and green supply chain management; this approach serves to satisfy the green claims 
of stakeholders. As a result, environmental management not only becomes a new business function within companies, but it also plays a more important role for routine business activities.

Intellectual capital is intangible factors underlying environmental capabilities that are the set of intangible resources and can provide firms with competitive advantages [2,3]. As mentioned by Chen [4], knowledge, intangible assets, or intellectual capital are antecedents of innovation. Bontis [5] argued social capital is one of three components of intellectual capital [5,6]. Scholars also empirically identified green social capital was related to green innovation [7].

Social capital refers to connections among individuals or organizations [8]. Social capital inheres in the structures of social relations among individuals or organizations [9]. It is the value, to actors, of particular aspects of a social structure as resources that actors can utilize to accomplish their goals [9]. One key facet of social capital is that social capital is, similarly to human capital, created by individuals or organizations to generate certain returns.

Social capital provides one means of achieving particular ends, similar to other forms of capital, such as human capital [9]. Therefore, social capital is regarded as a resource rather than as a component of social structures. Social capital theory emphasizes the development and the payoffs of social capital, and it explains how individuals and organizations invest in social relations [10]. Individuals and organizations can access rich and diverse resources for expected returns while using social capital [11]. Social capital now plays a more important role with regard to business operations than it used to. Consequently, the pursuit of social capital is a key driver for organizational success [9].

Many companies believe that it is unnecessary to invest resources in environmental management. They misunderstand environmental management as being an impediment to competitiveness and profitability [12]. Nevertheless, industrial pollution stems from nonproductive manufacturing activities and inefficient use of resources [13]. As environmental management allows for companies to boost their corporate image, improve green innovation performance [7], enhance manufacturing productivity, obtain competitive advantages [14], and increase profitability, more firms are eager to act as pioneers and to enjoy first-mover benefits in the field of environmental management [14-16]. No study has explored the subject of social capital in the field of environmental management, although social capital has become an emerging research trend in the fields of strategic management, organizational theory, and knowledge management. According to Granovetter [17] and Lewis and Chamlee-Wright [18], the concept of green social capital-defined as a valuable asset that can enable an actor to achieve environmental goals through the actor's own social relationships and subsequently access relevant environmental knowledge, information, or resources [19]. The respective research gap is filled using a green social capital model based on social capital theory: network trait-social capital-outcome. This study develops the core concept of green social capital and explores its managerial implications, antecedents, and consequences to accommodate the current prevalence of environmentalism.

In response to the worldwide prevalence of environmentalism, companies should not evade their environmental responsibilities; environmental challenges can be transferred into business opportunities that can be applied to carry out green social capital, which can further enhance green innovation performance. This study emphasizes the accurate evaluation of, and reorientation toward, the new environmental management concept of green social capital, in compliance with environmental pressures, with the intention of helping companies to improve their green innovation performance. Therefore, this research proposes five hypotheses and develops an green social capital model that is based on social capital theory. This study applies social capital theory to develop an original green social capital model, the network trait-social capital-outcome framework of environmental management. Thereby, the study explores the positive effects of network embeddedness and network diversity, through the partial mediator of green social capital, on the green innovation performance of a firm in a network. 


\section{Literature Review and Hypothesis Development}

\subsection{The Positive Effect of Network Embeddedness on Green Social Capital and Green Innovation Performance}

The two types of social capital are bonding social capital and bridging social capital [20,21]. Social capital means well-connected to utilize sharing resources and achieve their desired goals [22]. Based on this, trust and reciprocity are critical roles in the exchange and transition of information among network members. Social capital embedded within the network [23]. Coleman [24] mentioned that social capital is the relationship among individuals, which consists of aspects of social structure. Furthermore, social capital is the tangible and intangible resources embedded in social networks $[25,26]$. Therefore, social capital, structure or cognitive, is connecting with other members and enhances the positive impact of corporations to grow and success [23]. However, social capital, in its natural definition, is different to embeddedness. Granovetter [21] developed the concept of embeddedness within a social context. According to Granovetter's argument, embeddedness is the network of personal relations of actors, and the structure of the entire network of relationship will affect the economic actions, outcomes, and institutions. Hence, individual behaviors and institutions will be restricted by social relationships. Woolcock [27] uses the concepts of embeddedness and autonomy to determine those characteristics of social relations that contribute to welfare development and beneficial outcomes. Embeddedness refers to intracommunity ties that create cohesion among individuals to enhance their effectiveness in achieving collective goals, whereas autonomy focuses on the importance of intercommunity ties that prevent discrimination from and subordination to special interest groups [27].

The two types of network embeddedness are structural and relational network embeddedness [28]. Structural embeddedness is based on the position or structure of impersonal or interfirm linkages within a network [29]. Structural embeddedness reflects the impersonal or interfirm relationships and linkages among social actors or groups. Various aspects of structural embeddedness include the density, connectivity, and cohesion of network ties across agents, and would affect the bonding social capital [28]. Structural embeddedness influences managers' decision sets, because firms are embedded in a network's social relationships; therefore, it affects firms' competitive behavior [30]. Relational embeddedness reflects the relational characteristics of impersonal or interfirm connections within a network [21]. Relational embeddedness that is developed over a long period of time is a dimension of the stock of social capital that is enjoyed by an individual or an organization [31]. The characteristics of relational embeddedness are described in terms of trust, norms, respect, friendship, and values, and would affect the bridging social capital [32]. However, many researchers referred the relationship between excessive embeddedness of social capital and negative effects [33-35]. Hereby, this study argues that, according to the characteristics of structural embeddedness and relational embeddedness, a firm's network embeddedness positively affects its green social capital. Accordingly, the following hypothesis is proposed:

Hypothesis 1 (H1). A firm's network embeddedness is positively associated with its green social capital.

Embeddedness is the interdependency that develops over time from interpersonal or interfirm relationships [31]. Based on stakeholder theory, Freeman [36] pointed stakeholders can affect or be affected the achievement of the firms. Stakeholder theory argues that firms have to consider the interests of their stakeholders to obtain the support from their stakeholders while they make decisions or develop their strategies $[36,37]$. Furthermore, stakeholder theory points out that companies need to take the interests of their stakeholders into account to obtain the trust from their stakeholders, so they should embrace a long term sustainable vision to satisfy the claims and needs of their stakeholder [36-38]. Besides, Donaldson and Preston [39] argued that the structure and dimensions of corporations' societal relationships would affect the influence on corporations [40]. Thus, stakeholder's influence is the structural approach [41,42]. Additionally, as Rowley [41] noted, firms' stakeholders have direct relationships with one another. Further, the density of the stakeholder network is consistent with the 
findings from network research. In addition to structural embeddedness, relational embeddedness is also critical for the effectiveness of one's social capital [32]. Moran [43] determines that, although both forms of embeddedness matter for performance, structural embeddedness plays a stronger role in explaining execution-oriented tasks, and relational embeddedness plays a stronger role in explaining innovation-oriented tasks. Execution- and innovation-oriented task performance are both likely to benefit from network embeddedness [43]. Having more contacts can generate more alternatives for acquiring additional key resources and more innovative ideas and can enable more control over the use of those resources [44]. Closed networks may also have advantages for execution- and innovation-oriented tasks $[9,45]$. Both structural embeddedness and relational embeddedness reduce the uncertainty surrounding exchange and the risk that resources offer in exchange. For this reason, the advantages of network embeddedness that are provided through the formation of norms, routines, trust, and values are valuable for the innovation process [46].

Network embeddedness can help network members to enhance performance, because such networks are characterized by a higher network density, a greater number of connections, more cohesion, increased trust, and an improved culture of shared norms [47]. Network embeddedness increases when all the network members frequently communicate with each other [45,48-50]. Increased network embeddedness is thought to indicate enhanced capacity to coordinate its actions and to foster identification in the network and mutual trust, which facilitates exchange and collective action. Therefore, increases in network embeddedness can enhance innovation performance [47]. This study refers to the definition of Chen et al. [51] of green innovation performance as the performance of hardware and software involved in the innovation that a company achieves in relation to green products or processes, including technological innovations in energy saving, pollution prevention, waste recycling, green product design, or corporate environmental management. This study postulates that a firm's network embeddedness positively affects its green innovation performance and implies the following hypothesis, according to the aforementioned statement:

Hypothesis 2 (H2). A firm's network embeddedness is positively associated with its green innovation performance.

\subsection{The Positive Effect of Network Diversity on Green Social Capital and Green Innovation Performance}

Network diversity describes a configuration that encompasses a set of network members with diverse characteristics [52]. Network diversity provides access to diverse information, knowledge, resources, and capabilities, and it reduces redundancy [47]. Social capital relates to the features of social networks, associated norms, and trustworthiness that enable members to more effectively collaborate in pursuit of shared objectives [53]. Pendakur and Mata [54] suggest that bridging social capital can increase as network diversity increases. Burt [55] states that actors who occupy broker or bridging positions, structural holes, between subnetworks within networks benefit from having access to diverse pools of resources, information, and knowledge that are usually unavailable. Another method of studying the effect of brokerage on a network's social capital involves using the concept of network diversity (or network heterogeneity) [47].

Bringing together diverse actors is similar to bringing together members of different subnetworks that do not usually meet each other and that do not usually exchange much knowledge with one another [56]. Thus, diversifying actors implies creating more brokers or bridging positions, structural holes, between these subnetworks. Furthermore, diversifying actors provides access to a broad array of resources, information, and knowledge, as well as fostering new ideas and alternative views [57]. Networks demonstrating higher levels of network diversity create more bridging positions or structural holes in networks, such that the bridging dimension of social capital is higher [58]. Based on structural hole theory, network diversity is positively related to the social capital of an actor in 
this network [55]. According to the aforementioned statement, this study argues that a firm's network diversity positively affects its green social capital. As such, the following hypothesis is offered:

Hypothesis 3 (H3). A firm's network diversity is positively associated with its green social capital.

Network diversity refers to the diversity level of network members' characteristics [47]. If the networks are characterized by high network diversity, the relationships within the networks cut across salient boundaries, such that network members enjoy enhanced learning capability [47]. Ancona and Caldwell [59] argue that network members with diverse backgrounds can achieve superior performance, because diverse network members have different technical skills and different perspectives that can contribute more creative knowledge to the networks. Thus, having diverse network members can improve members' performance. The performance of members within a homogenous network is limited by the relative redundancy of members' data, perspectives, resources, and knowledge [59-61].

Heterogeneous members enjoy a higher capacity for innovative problem solving, as greater diversity entails relationships among members with different skills, contacts, experiences, data, and knowledge. Diversity in a network provides members with an opportunity to act as a bridge between actors that are usually disconnected from each other. Diverse members should perform at a superior level, because diversity enhances connections across boundaries. As diversity improves, network members allocate more of their effort and their network time to cross-boundary or boundary-spanning interactions [47]. Such boundary spanning generates informational benefits, because the nature of the information that is available within a homogeneous network becomes relatively redundant [55]. Ties between actors permit them access to broader ranges of perspectives, ideas, opportunities, and knowledge than actors that are restricted to specific areas can access [62]. An increase in network diversity is thought to facilitate learning and creativity, which results in enhanced performance. According to social capital theory, network members can capture value by bridging structural holes or gaps between the actors in a network [55]. As diversity within a network is beneficial for bridging such structural holes, diversity thereby enhances the capacity of the network for innovation [59-61]. Accordingly, this study argues that a firm's network diversity positively affects the firm's green innovation performance, which implies the following hypothesis:

Hypothesis 4 (H4). A firm's network diversity is positively associated with its green innovation performance.

\subsection{The Positive Effect of Green Social Capital on Green Innovation Performance}

Relevant research emphasizes the importance of social capital, which is one of the main drivers of firms' improved innovation performance. Powell et al. [63] demonstrate that firms that are embedded in an inter-organizational collaborative network become more innovative. Landry et al. [64] note that the social capital of firms is positively associated with the firms' innovativeness. One major contribution of social capital to innovation is reduced search and communication costs, transaction costs, bargaining costs, enforcement costs, and monitoring costs between firms and other actors [65]. Thus, social capital facilitates knowledge access, gives members a sense of belonging and identity, and enhances trust. Social capital plays an important role in facilitating knowledge seeking and sharing activities.

If companies rely on their external social networks to develop, create, and invent knowledge and ideas, social capital can help companies to access key resources and social relationships that enhance their innovation capabilities [66]. Social capital can integrate different actors' varying types of knowledge to achieve innovation [64], and can hence drive innovation performance [66-68]. For example, Landry et al. [64] note that an increase of social capital can enhance firms' innovation likelihood. Furthermore, Ahuja [56] reveals that the number of direct partners a firm has positively relates to its product innovation. Thus, a firm's social capital has a positive influence on its innovation 
performance [69]. Accordingly, this study argues that a firm's green social capital positively affects its green innovation performance, and the following hypothesis is given:

Hypothesis 5 (H5). The green social capital of a firm is positively associated with its green innovation performance.

No other study explores the topic of social capital in the field of environmental management, although social capital has become a hot topic in the fields of strategic management, social networks, and organizational theory. Based on the perspective of social capital, this study proposes a novel construct, green social capital, to fill the respective research gap. This study develops a research model, a network trait-social capital-outcome framework of environmental management, and it explores the positive effects of network embeddedness and a firm's network diversity on green innovation performance through the partial mediator of green social capital. In addition, this study employs empirical research to verify the research framework. The antecedents of the research framework in this study are network embeddedness and network diversity, the consequent is green innovation performance, and the partial mediator is green social capital, as illustrated in Figure 1.

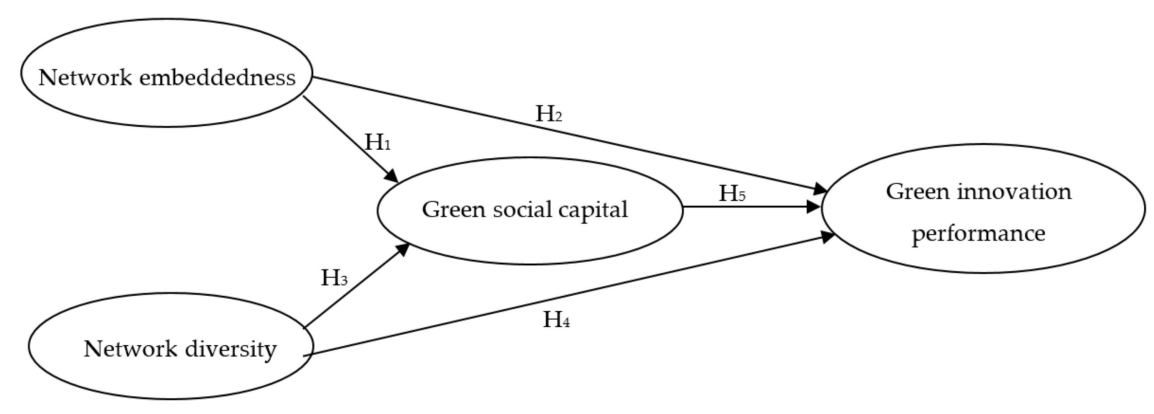

Figure 1. Research framework.

\section{Methodology and Measurement}

\subsection{Data Collection and the Sample}

Business level is the unit of analysis in this study. It employs quantitative research, conducted in the Taiwanese manufacturing industry. This study uses questionnaire surveys to test the research frameworks and the hypotheses that are presented in Figure 1. Although social capital is an emerging issue in the fields of strategic management, organizational management, and knowledge management, no study explores the subject of social capital in the field of environmental management. This study develops the core concept, green social capital, to fill the respective research gap, and it explores its managerial implications to accommodate the environmentalism that is currently prevalent. This study explores the influences of network embeddedness and network diversity on the green innovation performance of a firm within a network and it discusses the mediation effect of green social capital. The study employs a questionnaire survey to test the network trait-social capital-outcome framework of environmental management presented in Figure 1 by means of structural equation modeling (SEM).

The sample of questionnaire surveys is randomly selected from the 2016 Business Directory of China Credit Information Service, Ltd. The questionnaire respondents are the CEOs or the managers of environmental, manufacturing, marketing, HR, supply chain, logistics, or R\&D departments in Taiwanese manufacturing companies. We call on each company sampled to explain the objectives of the study and the questionnaire content and to confirm the names and job titles of the respondents prior to mailing out questionnaires to heighten the valid survey response rate. The respondents are asked to return the completed questionnaires by mail within two weeks.

According to the 303 valid questionnaires that were collected in this study, $49 \%$ of the selected firms are in the semiconductor industry, $9 \%$ are in the consumer electronics industry, $9 \%$ are in the IT 
industry, $5 \%$ are employed in the machine industry, $4 \%$ are in the computer industry, $3 \%$ are in the food industry, $2 \%$ are in the textile industry, $2 \%$ work in the chemical industry, $2 \%$ are in the optical industry, $1 \%$ are in communications, $1 \%$ are in the biotechnology industry, and $11 \%$ are in other industries in Table 1.

Table 1. The percentage of industries in the sample.

\begin{tabular}{cc}
\hline Industry & Percentage \\
\hline semiconductor & $49 \%$ \\
\hline consumer electronics & $9 \%$ \\
\hline IT & $9 \%$ \\
\hline machine & $5 \%$ \\
\hline computer & $4 \%$ \\
\hline food & $3 \%$ \\
\hline textile & $2 \%$ \\
\hline chemical & $2 \%$ \\
\hline optical & $2 \%$ \\
\hline communications & $1 \%$ \\
\hline biotechnology & $1 \%$ \\
\hline others & $11 \%$ \\
\hline
\end{tabular}

The study refers to the relevant literature to design questionnaire items for the questionnaire survey. Eight experts and scholars are asked to modify the questionnaire in the first pretest before questionnaires are mailed to respondents. Subsequently, the questionnaires are randomly mailed to twelve CEOs or managers from environmental, manufacturing, marketing, HR, supply chain, logistics, or R\&D departments in different Taiwanese manufacturing companies. These individuals are asked to fill in the questionnaires and identify ambiguities in terms, meanings, and issues in the second pretest. High content validity is a necessary requisition for the questionnaire in this study. Different respondents are used for different constructs in this study to avoid common method variance. For example, the respondents of green social capital are CEOs or managers of environmental departments; and, those of green innovation performance are CEOs or managers of environmental, manufacturing, or R\&D departments in Taiwanese manufacturing companies. For the respondents of network embeddedness and network diversity, the respondents regard their companies' networks as the focal ones to identify the level of network embeddedness and that of network diversity. The respondents whose questionnaires relate to network embeddedness are CEOs or managers of marketing, supply chain, or logistics departments; those whose questionnaires relate to network diversity are CEOs or managers of marketing, supply chain, or logistics departments. In this study, all of the constructs are measured using a seven-point Likert-type scale from 1 to 7.

\subsection{Measurements of the Constructs}

\subsubsection{Green Social Capital}

According to Granovetter [16] and Lewis and Chamlee-Wright [17], this study proposes a new concept, green social capital, and defines it as a valuable asset that can enable actors to achieve environmental goals-through the actors' social relationships-to access relevant environmental knowledge, information, or resources. According to Tsai and Ghoshal [70], the measurement of green social capital encompasses six items: (1) the frequency of communication within the company; (2) the density of connections within the company; (3) the degree of mutual trust within company interpersonal relationships; (4) the degree of mutual trust within company interunit relationships; (5) 
the existence of a shared vision within the company; and, (6) the existence of shared norms within the company [70].

\subsubsection{Network Embeddedness}

The respondents regard their companies' networks as the focal ones to figure out the level of network embeddedness. Embeddedness refers to the interdependency that develops over time among interpersonal or interfirm relationships [31]. According to Moran [43], the measurement of network embeddedness includes four items: (1) the density of a company's network; (2) the number of connections in a company's network; (3) the existence of mutual trust between network members; and, (4) the existence of social norms in the company's network [43].

\subsubsection{Network Diversity}

The respondents regard their firms' networks as the focal ones to identify the level of network diversity. Network diversity refers to the diversity level of the network members' characteristics [47]. According to Reagans and Zuckerman [47], the measurement of network diversity includes three items: (1) the range of industries spanned by a company's network members; (2) variation in the value chain activities of the company's network members; and, (3) variation in the business models of the company's network members [47].

\subsubsection{Green Innovation Performance}

This study refers to Chen et al. [51] in defining green innovation performance as the performance of hardware and software involved in the innovation that a company produces for green products or processes, including innovation in technologies that are related to energy saving, pollution prevention, waste recycling, green product design, and corporate environmental management. According to Chen et al. [51,71], the measurement of green innovation performance includes eight items: (1) the degree to which a company uses nonpolluting product materials for conducting product development or design; (2) the degree to which a company uses product materials that consume minimal energy and resources for product development or design; (3) to what degree the company minimizes the quantities of materials that are used for product development or design; (4) to what degree the company deliberates, circumspectly, on ease of recycling, reusability, and decomposability for product development and design; (5) to what degree the company reduces hazardous substance and waste emissions; (6) to what degree the manufacturing process of the company recycles waste and emissions that allow them to be treated and reused; (7) to what degree the company's manufacturing process minimizes consumption of water, electricity, coal, and oil; and, (8) to what degree the company's manufacturing process minimizes the use of raw materials [51]

\section{Empirical Results}

In this study, we use SEM to analyze the fitness of the full model by using the AMOS software program. Table 2 shows the results of the full model in this study. The overall fit measures of the full model in the SEM indicate that the fit of the model is acceptable (RMSEA $=0.045, \mathrm{CFI}=0.982, \mathrm{GFI}=0.918$, AGFI=0.892, IFI=0.982).

Table 2. Structural equation modeling (SEM) model fitness.

\begin{tabular}{cccccccc}
\hline $\mathbf{X}^{\mathbf{2}}$ & $\mathbf{D f}$ & $\boldsymbol{\chi} \mathbf{2} / \mathbf{d f}$ & RMSEA & CFI & GFI & AGFI & IFI \\
\hline 279.845 & 175 & 1.6 & 0.045 & 0.982 & 0.918 & 0.892 & 0.982 \\
\hline
\end{tabular}

\subsection{The Results of the Measurement Model}

Table 3 shows the mean, standard deviation, and correlation matrix. Table 3 shows positive correlations among the four constructs: network embeddedness, network diversity, green social capital, 
and green innovation performance. In addition, we use Fornell and Larcker's [72] measure of average variance extracted (AVE) to evaluate the discriminant validity of the measurement. The AVE measures the amount of variance that was captured by the construct through its items relative to the amount of variance due to the measurement error. The square root of a construct's AVE must be greater than the correlations between the construct and the other ones in the model to satisfy the discriminant validity requirement. For example, the respective square roots of the AVEs for the two constructs-network embeddedness and network diversity-are 0.852 and 0.838 , which are greater than the correlation between them in Table 3 (0.557). This demonstrates the adequate discriminant validity between the two constructs. The square roots of all constructs' AVEs in Table 3 of this study are greater than the correlations among all constructs in Table 3. Therefore, the discriminant validity of the measurement in this study is acceptable.

We refer to other research to design questionnaire items. We employ two pretests to revise the questionnaire before mailing questionnaires to respondents. Therefore, the measurement of this study is acceptable in terms content validity. Moreover, several measures confirm the reliability and validity of the measurement. One measure of reliability is the loading of each construct's individual items. With respect to the quality of the measurement model, the loadings $(\lambda)$ of all items of the four constructs that are listed in Table 3 are significant. Cronbach's $\alpha$ is another measure of reliability. Table 4 lists Cronbach's $\alpha$ for the four constructs. In general, the minimum Cronbach's $\alpha$ coefficient indicating reliability is 0.7 [73]. In Table 4, the Cronbach's $\alpha$ coefficient of network embeddedness is 0.919 ; that of network diversity is 0.870 ; that of green social capital is 0.942 ; and, that of green innovation performance is 0.953 . The reliability of the measurement in this study is acceptable, as the Cronbach's $\alpha$ coefficient for all constructs are more than 0.7 . In addition, the convergent validity of the construct is acceptable if the AVE of a construct is higher than 0.5. As presented in Table 3, the AVEs of the four constructs are $0.726,0.702,0.704$, and 0.707 , which are all higher than 0.5 . This indicates that the convergent validity of the measurement is acceptable. The reliability and validity of the measurement in this study are acceptable based on the aforementioned results.

\subsection{The Results of the Structural Models}

Four of the five paths estimated are significant, as presented in Table 5. Adding more paths in the research framework would not significantly improve the fit measures. The residuals of the covariance are small and are centered near 0 . 
Table 3. Means, standard deviations, discriminant validity and average variance extracted (AVE).

\begin{tabular}{|c|c|c|c|c|c|c|}
\hline Constructs & Mean & Standard Deviation & (A) & (B) & (C) & (D) \\
\hline (A) Network embeddedness & 5.311 & 1.092 & 0.852 & & & \\
\hline (B) Network diversity & 4.739 & 1.252 & $0.557 * *$ & 0.838 & & \\
\hline (C) Green social capital & 5.331 & 1.114 & $0.339 * *$ & $0.191 * *$ & 0.839 & \\
\hline (D) Green innovation performance & 4.901 & 1.192 & $0.515^{* *}$ & $0.507^{* *}$ & $0.327^{* *}$ & 0.841 \\
\hline
\end{tabular}

Table 4. The items' loadings $(\lambda)$ and the constructs' Cronbach's $\alpha$ coefficients and AVEs.

\begin{tabular}{|c|c|c|c|c|c|}
\hline Constructs & Items & $\lambda$ & Cronbach's $\alpha$ & AVE & The Square Root of AVE \\
\hline \multirow{4}{*}{ Network embeddedness } & NE1 & 0.928 & \multirow{4}{*}{0.919} & \multirow{4}{*}{0.726} & \multirow{4}{*}{0.852} \\
\hline & NE2 & $0.956^{* *}$ & & & \\
\hline & NE3 & $0.725^{* *}$ & & & \\
\hline & NE4 & $0.777^{* *}$ & & & \\
\hline \multirow{3}{*}{ Network diversity } & ND1 & 0.807 & \multirow{3}{*}{0.870} & \multirow{3}{*}{0.702} & \multirow{3}{*}{0.838} \\
\hline & ND2 & $0.906^{* *}$ & & & \\
\hline & ND3 & $0.797 * *$ & & & \\
\hline \multirow{6}{*}{ Green social capital } & GC1 & 0.868 & \multirow{6}{*}{0.942} & \multirow{6}{*}{0.704} & \multirow{6}{*}{0.839} \\
\hline & GC2 & $0.862 * *$ & & & \\
\hline & GC3 & $0.867^{* *}$ & & & \\
\hline & GC4 & $0.819^{* *}$ & & & \\
\hline & GC5 & $0.837^{* *}$ & & & \\
\hline & GC6 & $0.779 * *$ & & & \\
\hline \multirow{8}{*}{$\begin{array}{l}\text { Green innovation } \\
\text { performance }\end{array}$} & GIP1 & 0.840 & \multirow{8}{*}{0.953} & \multirow{8}{*}{0.707} & \multirow{8}{*}{0.841} \\
\hline & GIP2 & $0.862 * *$ & & & \\
\hline & GIP3 & $0.856^{* *}$ & & & \\
\hline & GIP4 & $0.853 * *$ & & & \\
\hline & GIP5 & $0.835^{* *}$ & & & \\
\hline & GIP6 & $0.820 * *$ & & & \\
\hline & GIP7 & $0.849^{* *}$ & & & \\
\hline & GIP8 & $0.812 * *$ & & & \\
\hline
\end{tabular}


Table 5. The results of the structural model.

\begin{tabular}{ccccc}
\hline Hypothesis & Proposed Effect & Path Coefficient & T-Value & Results \\
\hline H1 & + & $0.347 * *$ & 4.067 & supported \\
\hline H2 & + & $0.265 * *$ & 3.215 & supported \\
\hline H3 & + & 0.024 & 0.335 & not supported \\
\hline H4 & + & $0.404 * *$ & 5.734 & supported \\
\hline H5 & + & $0.228 * *$ & 3.656 & supported \\
\hline
\end{tabular}

Note: The number in the bracket is $\mathrm{t}$ value. ${ }^{*} \mathrm{p}<0.05,{ }^{* *} \mathrm{p}<0.01$. 
Speaking of the relationship between network embeddedness and green social capital, the standardized path coefficient of a firm's network embeddedness to its green social capital is 0.347 , which is significant $(\mathrm{p}<0.001) . \mathrm{H}_{1}$ is supported. Thus, the embeddedness of a company's network positively affects its green social capital.

The standardized path coefficient of a firm's network embeddedness to its green innovation performance is 0.265 with respect to the relationship between network embeddedness and green innovation performance, which is significant $(\mathrm{p}<0.001) . \mathrm{H}_{2}$ is supported. Hence, the embeddedness of a company's network positively affects its green innovation performance.

The standardized path coefficient of a firm's network diversity to its green social capital is 0.024 with regard to the relationship between network diversity and green social capital, which is not significant $(\mathrm{p}=0.737)$. Thus, $\mathrm{H}_{3}$ is not supported. The diversity of a company's network does not affect its green social capital.

Speaking of the relationship between network diversity and green innovation performance, the standardized path coefficient of a firm's network diversity to its green innovation performance is 0.404 , which is significant $(\mathrm{p}<0.001) . \mathrm{H}_{4}$ is supported. Therefore, the diversity of a company's network positively affects its green innovation performance.

The standardized path coefficient of a firm's green social capital to its green innovation performance is 0.228 with respect to the relationship between green social capital and green innovation performance, which is significant $(\mathrm{p}<0.001) . \mathrm{H}_{5}$ is supported. Hence, the green social capital of a firm positively affects its green innovation performance.

With regard to the verification of the mediation effect, the results demonstrate that $\mathrm{H}_{1}, \mathrm{H}_{2}, \mathrm{H}_{4}$, and $\mathrm{H}_{5}$ are supported, which means that green social capital plays a mediation role between network embeddedness and green innovation performance.

Figure 2 shows the results of the full model in this study. The four paths estimated are positive and significant. Therefore, $\mathrm{H}_{1}, \mathrm{H}_{2}, \mathrm{H}_{4}$, and $\mathrm{H}_{5}$ are supported, but $\mathrm{H}_{3}$ is not supported in this study. We reveal that network embeddedness positively affects both green social capital and green innovation performance. Firms can enhance the interdependency between their network members to raise their green social capital and green innovation performance. In addition, the relationship between network diversity and green social capital is not significant, although the results indicate that network diversity can positively influence green innovation performance. Thus, firms could improve the diversity level of their network members' characteristics to enhance green innovation performance. Furthermore, companies must develop their green social capital to raise their green innovation performance because the results indicate that green social capital positively relates to green innovation performance. 


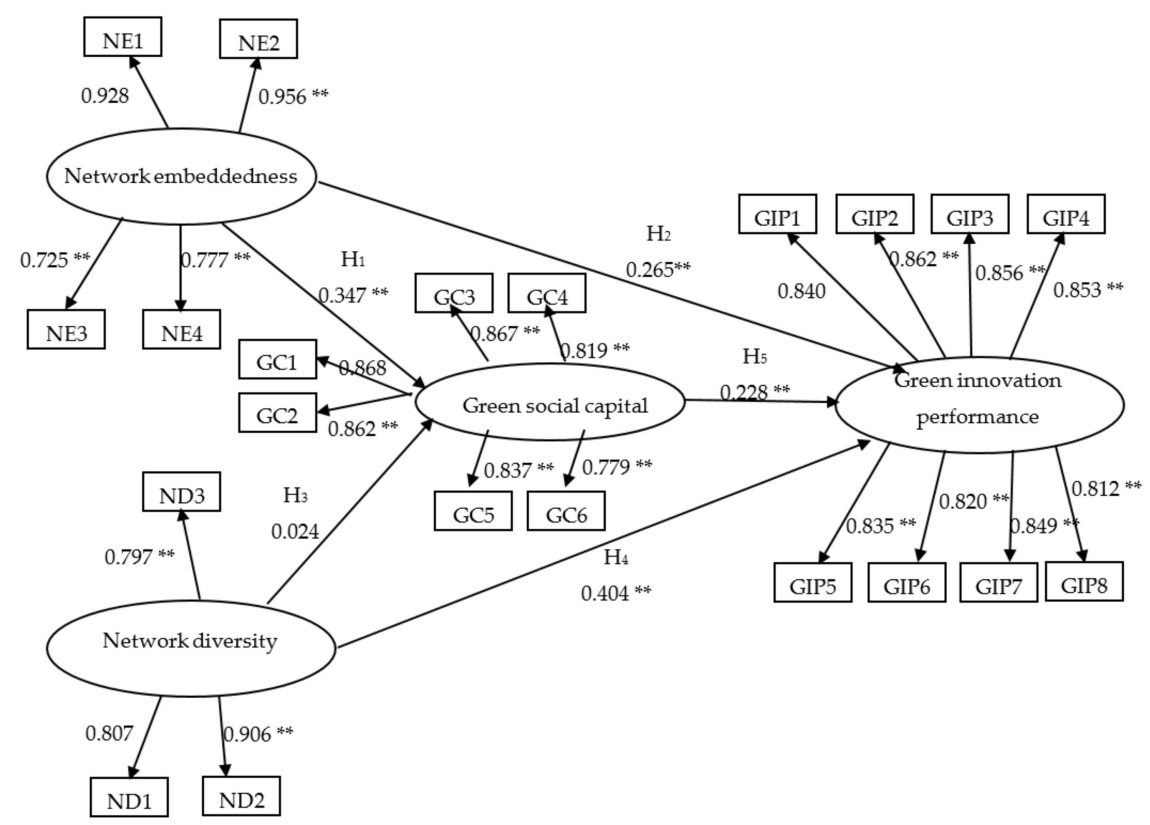

Figure 2. The results of the full model; RMSEA=0.045, CFI=0.982, GFI=0.918, AGFI=0.892, IFI=0.982; * $\mathrm{p}<0.05,{ }^{* *} \mathrm{p}<0.01$.

Network embeddedness and network diversity can both directly and positively relate to green innovation performance. We demonstrate that network embeddedness and network diversity are two crucial drivers of green innovation performance. In addition, we prove that green social capital partially mediates the positive relationship between network embeddedness and green innovation performance. This means that network embeddedness cannot only directly affect green innovation performance positively, but can also indirectly positively affect it through green social capital. However, green social capital does not mediate the positive relationship between network diversity and green innovation performance. Based on the aforementioned research results, we suggest that companies should raise their network embeddedness, network diversity, and green social capital to enhance their green innovation performance and enhance their corporate sustainability.

\section{Conclusions}

This study investigates the influence of network traits and of green social capital on green innovation performance within the context of corporate sustainability, and it infers that network embeddedness and network diversity affect green innovation performance. Green social capital is demonstrated to partially mediate the positive relationship between network embeddedness and green innovation performance. This means that network embeddedness can not only positively influence green innovation performance directly, but it also indirectly positively affects green innovation performance through green social capital.

However, the positive relationship between network diversity and green innovation performance is not mediated by green social capital. The result is similar to many past researches that supported the negative effect of excessive connection of social capital. Previous concepts of social capital were considered to pursue more linkages to others to absorb as many resources as they could in order to achieve their outcomes. Nevertheless, the exclusion, limitation of sharing benefit, restriction, and common experience and opinion would limit the expansion of network to connect to the social capital [22,23,33-35]. Based on this, the association between network diversity and green social capital is not generalizable.

The research results suggest that firms must enhance their network embeddedness, network diversity, and green social capital to increase their green innovation performance. In recent years, multinational companies have formed a collective competitive alliance that is based on cross-firm 
networks for sharing complementary resources; these companies actively engage in innovation with cooperative business networks, overcoming barriers to entering markets, achieving economies of scale, and expanding their business scope. Firms must seek new alliances, as the development of a firm's network relies on resources. The network embeddedness mechanism can help individual firms to determine which other firms to establish partnerships with [28,74-77]. According to the results of this study, network embeddedness and network diversity positively affect green innovation performance. That is, the more diverse an enterprise's network is and the greater the extent of its network embeddedness is, the more advanced the enterprises' green innovation performance is.

\subsection{Managerial Implications}

The results of this study demonstrate that green social capital improves green innovation performance. The more is green social capital acquired from networks or interfirm activities, the more resources and knowledge are, in turn, obtained from those. More frequent interactions between members in a network are more conductive to the establishment of green social capital. Enterprises are assisted in the enhancement of their green innovation performance if enterprises treat green communication as the main method of network interaction, to promote mutual understanding of environmental management.

Based on this, although social capital is viewed to positively impact to corporations' growth, it is vital to select appropriate partners for supply, distribution, and strategic alliances, enterprises choose a multi-objective business alliance for assessing its advantages and disadvantages within the competitive environment. By means of interacting with network members, maintaining intensive links, enhancing trust, and regulating each other, members promote the exchange of implicit knowledge, stimulate business thinking, facilitate green innovation performance, and further increase green product and process performance.

\subsection{Limitations and Future Research Opportunities}

Although we discuss the effects of network embeddedness and network diversity on green innovation performance and regard green social capital as the mediator variable, it is recommended that scholars consider other key factors as determinants for further research. This study is based on the Taiwanese manufacturing industry. It is recommended that future studies use comparative analysis methods to explore different results in different industries, as different results are likely to emerge from different groups or industries. Second, the corporate culture is very different between the East and the West. Future studies can consider a comparative view of cultural dimensions to probe other facets. Third, the association between network density and green social capital would have different function from one context to another. Future researches can consider additional facets that are based on the development of strategic alliance, such as complementary capital, to solid the association. Finally, this study collects questionnaire data at only one point in time; we suggest that future studies verify the research framework by means of a longitudinal study.

Author Contributions: Conceptualization, Y.-S.C.; methodology, C.W.; software, K.-L.C.; validation, Y.-R.C.; formal analysis, W.-Y.L.; investigation, Y.-S.C.; resources, K.-L.C.; data curation, C.W.; writing-original draft preparation, Y.-S.C.; writing-review and editing, Y.-R.C.; visualization, W.-Y.L.; supervision, Y.-S.C.; project administration, C.W.; funding acquisition, Y.-S.C.

Funding: This research was funded by Ministry of Science and Technology (MOST) in Taiwan, grant number MOST 104-2410-H-305-070-MY2.

Conflicts of Interest: The authors declare no conflict of interest.

\section{References}

1. Dechant, K.; Altman, B. Environmental leadership: From compliance to competitive advantage. Acad. Manag. Exec. 1994, 8, 7-20. [CrossRef] 
2. Martin-De Castro, G.; Delgado-Verde, M.; Lopez-Saez, P.; Navas-Lopez, J.E. Towards 'an intellectual capital-based view of the firm': Origins and nature. J. Bus. Ethics 2010, 98, 649-662. [CrossRef]

3. Martin-De Castro, G.; Delgado-Verde, M.; Navas-Lopez, J.E.; Cruz-Gonzalez, J. The moderating role of innovation culture in the relationship between knowledge assets and product innovation. Technol. Forecast. Soc. Chang. 2013, 80, 351-363. [CrossRef]

4. Chen, Y.S. The positive effect of green intellectual capital on competitive advantages of firms. J. Bus. Ethics 2008, 77, 271-286. [CrossRef]

5. Bontis, N. Intellectual capital: An exploratory study that develops measures and models. Manag. Decis. 1998, 36, 63-76. [CrossRef]

6. Reed, K.K.; Lubatkin, M.; Srinivasan, N. Proposing and testing an intellectual capital-based view of the firm. J. Manag. Stud. 2006, 43, 867-893. [CrossRef]

7. Delgado-Verde, M.; Amores-Salvadó, J.; Martín-de Castro, G.; Navas-López, J.E. Green intellectual capital and environmental product innovation: The mediating role of green social capital. Knowl. Manag. Res. Pract. 2014, 12, 261-275. [CrossRef]

8. Putnam, R.D. Bowling Alone. The Collapse and Revival of American Community; Simon \& Schuster: New York, NY, USA, 2000.

9. Coleman, J.S. Foundations of Social Theory; Belknap Press of Harvard University Press: Cambridge, MA, USA, 1990.

10. Lin, N.; Erickson, B.H. Social Capital. An International Research Program; Oxford University Press: New York, NY, USA, 2008.

11. Dayton-Johnson, J. Social capital, social cohesion, community: A microeconomic analysis. In The Economic Implications of Social Cohesion; Osberg, L., Ed.; University of Toronto Press: Toronto, ON, USA, 2003; pp. $43-78$.

12. Chang, C.H.; Chen, Y.S. The determinants of green intellectual capital. Manag. Decis. 2012, 50, 74-94. [CrossRef]

13. Hart, S.L. A natural-resource-based view of the firm. Acad. Manag. Rev. 1995, 20, 986-1014. [CrossRef]

14. Lin, Y.H.; Chen, Y.S. Determinants of green competitive advantage: The roles of green knowledge sharing, green dynamic capabilities, and green service innovation. Qual. Quant. 2017, 51, 1663-1685. [CrossRef]

15. Porter, M.E.; Van der Linde, C. Green and Competitive. Harv. Bus. Rev. 1995, 73, 120-134.

16. Granovetter, M.S. Problems of explanation in economic sociology. In Networks and Organizations; Nohria, N., Eccles, R.G., Eds.; Harvard Business School Press: Boston, MA, USA, 1992; pp. 25-56.

17. Lewis, P.; Chamlee-Wright, E. Social embeddedness, social capital and the market process: An introduction to the special issue on Austrian economics, economic sociology and social capital. Rev. Austrian Econ. 2008, 21, 107-118. [CrossRef]

18. Christoforou, A. On the identity of social capital and the social capital of identity. Camb. J. Econ. 2013, 37, 719-736. [CrossRef]

19. Dean, A.; Kretschmer, M. Can ideas be capital? Factors of production in the postindustrial economy: A review and critique. Acad. Manag. Rev. 2007, 32, 573-594. [CrossRef]

20. Mazumdar, S.; Learnihan, V.; Cochrane, T.; Davey, R. The Built Environment and Social Capital: A Systematic Review. Environ. Behav. 2018, 50, 119-158. [CrossRef]

21. Granovetter, M. Economic Action and Social Structure: The Problem of Embeddedness. Am. J. Sociol. 1985, 91, 481-510. [CrossRef]

22. Birendra, K.C.; Morais, D.B.; Seekamp, E.; Smith, J.W.; Peterson, M.N. Bonding and bridging forms of social capital in wildlife tourism microentrepreneurship: An application of social network analysis. Sustainability 2018, 10, 315.

23. Birendra, K.C.; Morais, D.B.; Smith, J.W.; Peterson, M.N.; Seekamp, E. Using social network analysis to understand trust, reciprocity, and togetherness in wildlife tourism microentrepreneurship. J. Hosp. Tour. Res. 2019, 20. [CrossRef]

24. Coleman, J.S. Social theory, social research, and a theory of action. Am. J. Soc. 1986, 91, 1309-1335. [CrossRef]

25. Greve, A.; Salaff, J.W. Social networks and entrepreneurship. Entrep. Theory Pract. 2003, 28, 1-22. [CrossRef]

26. Neergaard, H.; Shaw, E.; Carter, S. The impact of gender, social capital and networks on business ownership: A research agenda. Int. J. Entrep. Behav. Res. 2005, 11, 338-357. [CrossRef]

27. Woolcock, M. Social capital and economic development: Toward a theoretical synthesis and policy framework. Theory Soc. 1998, 72, 151-208. [CrossRef] 
28. Gulati, R. Network location and learning: The influence of network resources and firm capabilities on alliance formation. Strateg. Manag. J. 1999, 20, 397-420. [CrossRef]

29. Baum, J.C.; Dutton, J.E. Introduction: The Embeddedness of Strategy. Strateg. Manag. J. 1996, 20, $251-278$. [CrossRef]

30. Gnyawali, D.R.; Madhavan, R. Cooperative networks and competitive dynamics: A structural embeddedness perspective. Acad. Manag. Rev. 2001, 26, 431-445. [CrossRef]

31. Sporleder, T.L.; Moss, L.A.E. Knowledge management in the global food system: Network embeddedness and social capital. Am. J. Agric. Econ. 2002, 84, 1345-1352. [CrossRef]

32. Nahapiet, J.; Ghoshal, S. Social capital, intellectual capital, and the organizational advantage. Acad. Manag. Rev. 1998, 23, 242-266. [CrossRef]

33. Agnitsch, K.; Flora, J.; Ryan, V. Bonding and bridging social capital: The interactive effects on community action. Community Dev. 2006, 37, 36-51. [CrossRef]

34. Eklinder-Frick, J.; Eriksson, L.; Hallén, L. Bridging and bonding forms of social capital in a regional strategic network. Ind. Mark. Manag. 2011, 40, 994-1003. [CrossRef]

35. Portes, A. Social capital: Its origins and applications in modern sociology. Annu. Rev. Soc. 1998, 24, 1-24. [CrossRef]

36. Freeman, R.E. Strategic Management: A Stakeholder Perspective; Prentice Hall: Englewood Cliffs, NJ, USA, 1984.

37. Mitchell, R.K.; Agle, B.R.; Wood, D.J. Toward a Theory of Stakeholder Identification and Salience: Defining the Principle of Who and What Really Counts. Acad. Manag. Rev. 1997, 22, 853-886. [CrossRef]

38. Prakash, A. Green marketing, public policy and managerial strategies. Bus. Strategy Environ. 2002, 11, $285-297$. [CrossRef]

39. Donaldson, T.; Preston, L.E. The stakeholder theory of the corporation: Concepts, evidence, and implications. Acad. Manag. Rev. 1995, 20, 65-91. [CrossRef]

40. Yang, A.; Taylor, M. Looking over, looking out, and moving forward: A network ecology framework to position public relations in communication theory. Commun. Theory 2015, 25, 91-115. [CrossRef]

41. Rowley, T.J. Moving beyond dyadic ties: A network theory of stakeholder influences. Acad. Manag. Rev. 1997, 22, 887-910. [CrossRef]

42. Frooman, J.; Murrell, A.J. Stakeholder influence strategies: The roles of structural and demographic determinants. Bus. Soc. 2005, 44, 3-31. [CrossRef]

43. Moran, P. Structural vs. relational embeddedness: Social capital and managerial performance. Strateg. Manag. J. 2005, 26, 1129-1151. [CrossRef]

44. Emerson, R.M. Power-dependence relations. Am. Sociol. Rev. 1962, 27, 31-41. [CrossRef]

45. Coleman, J.S. Social capital in the creation of human capital. Am. J. Sociol. 1988, 94, 95-120. [CrossRef]

46. Walker, G.; Kogut, B.; Shan, W. Social capital, structural holes and the formation of an industry network. Organ. Sci. 1997, 8, 109-125. [CrossRef]

47. Reagans, R.; Zuckerman, E.W. Networks, diversity, and productivity: The social capital of corporate R\&D teams. Organ. Sci. 2001, 12, 502-517.

48. Clercq, D.D.; Thongpapanl, N.; Voronov, M. Sustainability in the Face of Institutional Adversity: Market Turbulence, Network Embeddedness, and Innovative Orientation. J. Bus. Ethics 2018, 148, 437-455. [CrossRef]

49. Kuchmaner, C.A.; Wiggins, J.; Grimm, P.E. The Role of Network Embeddedness and Psychological Ownership in Consumer Responses to Brand Transgressions. J. Interact. Mark. 2019, 47, 129-143. [CrossRef]

50. Liu, F.H.; Chen, L.J.; Tsou, H.T. Suppliers' local network embeddedness and buyers' joint innovation. Int. Mark. Rev. 2019, 36, 342-364. [CrossRef]

51. Chen, Y.S.; Lai, S.B.; Wen, C.T. The influence of green innovation performance on corporate advantage in Taiwan. J. Bus. Ethics 2006, 67, 331-339. [CrossRef]

52. Ely, R.J.; Thomas, D.A. Cultural diversity at work: The effects of diversity perspectives on work group processes and outcomes. Adm. Sci. Q. 2001, 46, 229-273. [CrossRef]

53. Putnam, R.D. Bowling alone: America's declining social capital. J. Democr. 1995, 6, 65-78. [CrossRef]

54. Pendakur, R.; Mata, F. Social capital formation and diversity: Impacts of individual and place-related characteristics. J. Ethn. Migr. Stud. 2012, 38, 1491-1511. [CrossRef]

55. Burt, R. Structural Holes; Harvard University: Cambridge, MA, USA, 1992.

56. Ahuja, G. Collaboration networks, structural holes, and innovation: A longitudinal study. Adm. Sci. Q. 2000, 45, 425-455. [CrossRef] 
57. Burt, R.S. Structural holes and good ideas. Am. J. Sociol. 2004, 110, 349-399. [CrossRef]

58. Tortoriello, M.; Krackhardt, D. Activating cross-boundary knowledge: The role of simmelian ties in the generation of innovations. Acad. Manag. J. 2010, 53, 167-181. [CrossRef]

59. Ancona, D.G.; Caldwell, D.F. Demography and design: Predictors of new product team performance. Organ. Sci. 1992, 3, 321-341. [CrossRef]

60. Bantel, K.A.; Jackson, S.E. Top management and innovations in banking: Does the composition of the top team make a difference? Strateg. Manag. J. 1989, 10, 107-124. [CrossRef]

61. Pelled, L.H.; Eisenhardt, K.M.; Xin, K.P. Exploring the black box: An analysis of work group diversity, conflict, and productivity. Adm. Sci. Q. 1999, 44, 1-28. [CrossRef]

62. Granovetter, M.S. The strength of weak ties. Am. J. Sociol. 1973, 79, 1360-1380. [CrossRef]

63. Powell, W.W.; Koput, K.; Smith-Doerr, L. Interorganizational collaboration and the locus of innovation: Networks of learning in biotechnology. Adm. Sci. Q. 1996, 41, 116-145. [CrossRef]

64. Landry, R.; Amara, N.; Lamari, M. Does social capital determine innovation? Technol. Forecast. Soc. Chang. 2002, 69, 681-701. [CrossRef]

65. Maskell, P. Social capital innovation, and competitiveness. In Social Capital: Critical Perspectives; Baron, S., Field, J., Schuller, T., Eds.; Oxford University Press: New York, NY, USA, 2000; pp. 111-123.

66. Zheng, W. A social capital perspective of innovation from individuals to nations: Where is empirical literature directing us? Int. J. Manag. Rev. 2010, 12, 151-183. [CrossRef]

67. Chen, Y.S.; Chang, T.W.; Lin, C.Y.; Lai, P.Y.; Wang, K.H. The Influence of Proactive Green Innovation and Reactive Green Innovation on Green Product Development Performance: The Mediation Role of Green Creativity. Sustainability 2016, 8, 966. [CrossRef]

68. Chen, Y.S.; Hung, S.T.; Wang, T.Y.; Huang, A.F.; Liao, Y.W. The Influence of Excessive Product Packaging on Green Brand Attachment: The Mediation Roles of Green Brand Attitude and Green Brand Image. Sustainability 2017, 9, 654. [CrossRef]

69. Martínez-Cañas, R.; Sáez-Martínez, F.J.; Ruiz-Palomino, P. Knowledge acquisition's mediation of social capital-firm innovation. J. Knowl. Manag. 2012, 16, 61-76. [CrossRef]

70. Tsai, W.; Ghoshal, S. Social capital and value creation: The role of intrafirm networks. Acad. Manag. J. 1998, 41, 464-476.

71. Chen, Y.S.; Lin, Y.H.; Lin, C.Y.; Chang, C.W. Enhancing Green Absorptive Capacity, Green Dynamic Capacities and Green Service Innovation to Improve Firm Performance: An Analysis of Structural Equation Modeling (SEM). Sustainability 2015, 7, 15674-15692. [CrossRef]

72. Fornell, C.; Larcker, D.F. Evaluating Structural Equation Models with Unobservable Variables and Measurement Error. J. Mark. Res. 1981, 18, 39-50. [CrossRef]

73. Hair, J.F.; Anderson, R.E.; Tatham, R.L.; Black, W.C. Multivariate Data Analysis; Prentice-Hall, Inc.: Upper Saddle River, NJ, USA, 1998.

74. Allameh, S. Antecedents and consequences of intellectual capital. J. Intellect. Cap. 2018, 19, 858-874. [CrossRef]

75. Chen, Y.S.; Chang, C.H. Utilize structural equation modeling (SEM) to explore the influence of corporate environmental ethics: The mediation effect of green human capital. Qual. Quant. 2013, 47, 79-95. [CrossRef]

76. Chen, Y.S.; Chang, C.H.; Lin, Y.H. The Determinants of Green Radical and Incremental Innovation Performance: Green Shared Vision, Green Absorptive Capacity, and Green Organizational Ambidexterity. Sustainability 2014, 6, 7787-7806. [CrossRef]

77. Kawai, N.; Strange, R.; Zucchella, A. Stakeholder pressures, EMS implementation, and green innovation in MNC overseas subsidiaries. Int. Bus. Rev. 2018, 27, 933-946. [CrossRef]

(C) 2019 by the authors. Licensee MDPI, Basel, Switzerland. This article is an open access article distributed under the terms and conditions of the Creative Commons Attribution (CC BY) license (http://creativecommons.org/licenses/by/4.0/). 